\title{
Strategies of Sino-American Rivalry in Africa: From 2000 to COVID-19
}

\author{
Earl Conteh-Morgan \\ University of South Florida, Tampa, Florida, USA \\ 凶conteh@usf.edu
}

\begin{abstract}
In this article it is argued that Sino-American rivalry in Africa is based on competing strategies utilized by each power to enhance their interests and bilateral ties on the continent, as well to try and outdo each other in image projection and overall influence expansion. These strategies of rivalry and power enhancement revolve around promoting close military ties and transactions on the continent; the framing of the continent in the language of securitization and strategic importance; and the perennial utilization of discourse or narrative that frames the other as detrimental to the interests of African states. These strategies of containing the others power preponderance or influence have expanded to include what is now referred to as vaccine diplomacy on the part of China, and during the Trump Administration the raising of loud alarm bells of China trying to dispossess Africa through what could be referred to as the "debt trap". The consequences of these competing strategies enhance the following: authoritarianism in some key African states; increased jihadism in some regions of Africa as a reaction to the presence of the two major powers on the continent; weapons implicated in state violence and war crimes; and less money available for development as a result of resources being diverted to militarization. The ongoing pandemic will add another dimension to the US - China rivalry as both powers try to project an image of being the most concerned about Africa on as it relates to combating the virus.
\end{abstract}

Key words: Africa, United States, China, militarization and securitization, discourse, vaccine diplomacy

For citation: Conteh-Morgan, E. (2021). Strategies of Sino-American Rivalry in Africa: From 2000 to COVID-19. Vestnik RUDN. International Relations, 21(2), 265-278. https://doi.org/10.22363/2313-0660-2021-21-2-265-278

\section{Стратегии китайско-американского соперничества в Африке: с 2000 г. до пандемии COVID-19}

\author{
Э. Конте-Морган \\ Университет Южной Флориды, Тампа, Флорида, США \\ $\bowtie$ conteh@usf.edu
}

\begin{abstract}
Аннотация. Утверждается, что китайско-американское соперничество в Африке основано на конкурирующих стратегиях, используемых каждой державой для укрепления своих интересов и двусторонних связей на континенте, а также реализации попыток превзойти друг друга в проецировании имиджа и общем расширении влияния. Стратегии соперничества и усиления влияния вращаются вокруг содействия тесным военным связям и сделкам на континенте, формирования континента на языке секьюритизации и стратегической важности и постоянного использования дискурса или нарратива, который изображает соперника наносящим ущерб интересам африканских государств. Стратегии сдерживания превосходства или влияния других сил расширились, включив в себя то, что сейчас называется вакцинной дипломатией со стороны Китая, и во время президентства Д. Трампа из США раздавались четкие тревожные сигналы, означающие
\end{abstract}

(C) Conteh-Morgan E., 2021

This work is licensed under a Creative Commons Attribution 4.0 International License.

https://creativecommons.org/licenses/by/4.0/ 
обеспокоенность Вашингтона попытками Китая маргинализировать Африку посредством так называемой «долговой ловушки». Последствия этих конкурирующих стратегий усиливают авторитаризм в некоторых ключевых африканских государствах, рост джихадизма в ряде регионов Африки в ответ на присутствие двух крупных держав на континенте, случаи применения оружия в рамках государственного насилия и военных преступлений, а также сокращение средств для развития в результате отвлечения ресурсов на милитаризацию. Продолжающаяся пандемия добавит еще одно измерение к соперничеству между США и Китаем, поскольку обе державы пытаются позиционировать себя как страны, наиболее обеспокоенные борьбой с вирусом в Африке.

Ключевые слова: Африка, США, Китай, милитаризация и секьюритизация, дискурс, вакцинная дипломатия

Для цитирования: Conteh-Morgan E. Strategies of Sino-American Rivalry in Africa: From 2000 to COVID-19 // Вестник Российского университета дружбы народов. Серия: Международные отношения. 2021. Т. 21. № 2. C. 265 -278. DOI: $10.22363 / 2313-0660-2021-21-2-265-278$

\section{Introduction}

Africa has often been at the receiving end of external great power pressures manifested in geo-economic, geopolitical, military, and sociocultural structures in the international system. These structures of dominance have accordingly produced "scrambles" for political, economic, diplomatic, and cultural influence in the continent. In particular, the coexistence of three heritages - Indigenous, Islam, and Western [Mazrui 1986] in the continent have at times provoked violent conflicts and extremism in some African countries. It is not just radical jihadism and other violent conflicts but civil strife resulting from blatant economic inequality introduced by capitalism, and the tension between authoritarian tendencies and democratic values that produce both internal systemic insecurities for incumbent regimes and external systemic threats for great powers that impel both to engage in competitive influence strategies on the continent.

The objective of this article is to examine the US - China rivalry or competitive behaviors on the continent in the areas of economics, politics, militarization and diplomacy. In other words what competitive political, economic, military, and diplomatic strategies does each country use to try and outdo the influence of the other? The dependent status of African states provokes activities by the great powers to protect their economic, political, diplomatic, or cultural interests within African states.

This analysis is predicated on the argument that the rivalry and deepening involvement of the two most powerful economic entities (the U.S. and China) in Africa has ignited an ongoing competition for dominance on a continent that was once considered of very marginal importance to the great powers. In other words, how has American and Chinese rivalry and/or presence increased militarization and securitization on the continent?

The analysis will focus first on how the relationship between increasing terrorist attacks, internal rebellions against incumbent state regimes, incidents of piracy, have been used as a strategy / motivation for both powers to increase their influence in Africa and further cement their bilateral relationships in competition with one another; second on what the role of discourse / narrative has been in the attempt by both powers to win the hearts of African leaders and peoples, and third on the nature of the ongoing COVID-19 diplomacy in enhancing the image of each power on the continent Stated differently, in what ways have the two largest economies of the world conducted their rivalry on the continent? What activities constitute strategies of SinoAmerican rivalry on the continent?

The popular consensus that Africa is nongeo-strategic is in fact generally inaccurate. It is the continent that has received the most attention by great powers as manifested in the 19th century European scramble for colonies that balkanized it into over 50 states, the ideological Cold War rivalry of the immediate post WWII period, and the current rivalry and focus of China and the United States along with the growing interest and presence of middle and emerging powers like Russia, Turkey, Iran, Japan, and 
Brazil, and India, among others ${ }^{1}$. In other words, while not as evident as the ongoing reference to the Sino-American rivalry on the continent, other major powers are also in competition to carve out a strategic foothold in the continent. In particular, the Sino-American rivalry and/or convergence of military and security interests on the continent have markedly contributed to an ongoing militarization and securitization of the continent.

These two largest economies are perennially competing for geopolitical and economic advantages defined in terms of strategic resources, trade and investment outlets, diplomatic and political influence within its many nation-states [Hong 2008]. While the competition over Africa by the more powerful states is now mostly over economic influence, the goal of maintaining hegemonic dominance for the US and protecting geo-economic interests by China has naturally produced a need to protect those interests by both countries via a growing and robust military presence in the continent.

\section{Militarization and Securitization Strategies in Africa}

Sino-American militarization of Africa is the increased deployment and accumulation of capabilities (armed forces, arms transfers, and military bases) as a result of factors such as the war on terrorism, piracy, domestic rebellions against incumbent regimes, a logical need to protect expanding geopolitical and economic interests, as part of the quiet and ongoing greatpower rivalry in the continent, or as a result of expected great power responsibilities. Militarization is therefore comprised of arms transfers, troop deployment, peacekeeping activities, military engagement against terrorist groups, anti-piracy activities, military training and advising, and the establishment of military bases [Albrecht 1977; Nsia-Pepra 2014; Keenan 2008]. All these activities are pursued by the United States and China in order to have a

\footnotetext{
1 Weingraff L. China vs the US: The new imperial scramble for Africa // Red pepper. May 23, 2018. URL: https://www.redpepper.org.uk/china-vs-the-us-the-newimperial-scramble-for-africa/ (accessed: 03.01.2021).
}

permanent military presence on the continent aimed at ensuring the security of their interests and to compete for more influence relative to each other.

Militarization takes the form of strengthening African militaries through joint training, and combat activities with better equipped American and Chinese troops in order to forestall or contain terrorist attacks against economic, diplomatic, and other interests. Militarization could therefore be conceptualized as Africa's propensity to attract external troops and military technology as a result of terrorist attacks which pose a threat to the interests of great powers.

Inherent in militarization is the securitization of Africa by both powers. This is the verbal (oral and written) articulation of the geostrategic importance of Africa by both the US and China [Balzacq 2005]. Such articulation is manifested in policy statements whereby terrorism, rebellion, piracy, or violence in Africa have been deemed of such extreme threat to the national security and geo-economic interests of the US and China that they are contained by and dealt with by military strategy and tactics directed at eliminating them. Besides, US anxiety about the activities of China in Africa has been articulated by the most recent National Security Strategy of the United States as a development alarming to US national security ${ }^{2}$. In other words, the fact of China's heavy presence, and growing involvement in the continent has been securitized, that is viewed as a "threat to US national security".

China's presence and activities in the continent have been elevated to the level of high politics as opposed to low politics. Similarly, China's decision in 2013 to deploy combat troops to Mali and to send troops to protect its investments in South $\mathrm{Sudan}^{3}$ is an indication by

\footnotetext{
2 The 2017 National Security Strategy of the United States // Homeland Security Digital Library. URL: https://www.hsdl.org/?abstract\&did=806478 (accessed: 03.01.2021).

${ }^{3}$ Moscoe A. Crouching Tiger, Blue Helmet: Chinese Combat Troops in UN Peace Operations // E-International Relations. October 3, 2015. URL: https:/www.e-ir.info/ 2015/10/03/crouching-tiger-blue-helmet-chinese-combattroops-in-un-peace-operations/ (accessed: 03.01.2021).
} 
China to designate rebel violence and terroristic developments in Africa as a security threat to its geopolitical and economic interest in the continent and to signal to African countries that it is invested in Africa.

In the case of both the US and China in Africa "speech act" has progressed to the actual setting up of military bases and deployment of combat troops to ensure the security of their geopolitical and economic investments [ContehMorgan, Weeks 2016]. China, in other words, has been willing to dilute its longstanding foreign policy of non-interference and add to its involvement in traditional peacekeeping and peacebuilding activities the need to engage in military combat in order to protect its interests in Africa. For China, the threat of terrorism, and piracy to its vested interests in Africa has even impelled it to upgrade potential threats from a low political priority concern, to a high political priority one, and hence the need to deploy combat troops, and establish its first ever foreign naval base in Djibouti. Securitization of Africa is therefore a process that has evolved from foreign policy doctrine and/or speech act to the implementation of the speech act strategy into practical tactics such as joint military exercises, establishment of military bases, cooperation in combatting the threat, and ensuring that African militaries become more effective at containing threats to the national security of the state and external state actors with interests to protect.

Militarization in Africa is also the accumulation of both small arms and light weapons (SALWs), and at times the transfer of more sophisticated and costly weapons systems as well as the increase in and training of professional soldiers along with the establishing of military bases, and cooperation between external great power militaries and African militaries. African states to a very large extent fall into a category of militarization that is largely dependent on large scale arms imports and related technology, training in war fighting strategy, and strategic doctrines. In short, militarization in African countries is largely "dependent" militarization [Wendt, Barnett 1993]. Besides, the fact that African regimes often lack legitimacy, and this coupled with the perennial reality of gross economic inequalities, relative deprivation, which generate social unrest, impels regimes to militarize in order to contain security threats against their survival [Gelot, Sandor 2019]. This threat to regime survival generates a self-preservative behavior on the part of incumbent regimes.

Accordingly the decision to militarize is facilitated by the willingness and economic calculus of more developed countries to generate revenue through arms sales and other military technology; the determination by the US and China to strengthen their political and diplomatic ties with specific African states through this military cooperation relationship; the need to protect their citizens and economic interests in a specific African country; and the overall need of helping the incumbent regime survive violent extremism which in turn means protecting its local and national interest in general. Militarization becomes systemic or a permanent relationship between great powers and an African country because of the perennial security threat that is posed by either domestic or externally driven violent extremism.

\section{The US Contribution to Militarization and Securitization of Africa}

With the creation of the United States Africa Command (AFRICOM) in $2007^{4}$ following the increase in violent extremism and China's heavy engagement in the continent, the US has upgraded its geostrategic and security view of Africa. Accordingly, it has widened the scope of its militarization in the continent. Whereas its previous focus was just arms sales, now it has done the following: deployed over 6000 troops all over the continent; installed drones in many locations to beef up security; and established mini bases in specific African countries such as Niger, Uganda, and Gabon, among others. AFRICOM's location in Djibouti serves as the

4 Hanson S. U.S. Africa Command (AFRICOM) // Council on Foreign Relations. February 3, 2010. URL: https://www.cfr.org/backgrounder/us-africa-commandafricom (accessed: 11.01.2021). 
hub of militarization along with close to 50 other states serving as outposts or contingency sites ${ }^{5}$. This militarization and securitization of Africa is, in other words, manifested in a key military base in Djibouti, backed by mini forward bases, drone locations, and concentration of troops in more stable democratic states is due to a dominant belief within the US security community and the Department of Defense that violent extremism and radical jihadism is on the increase in Africa.

The US through military cooperation with African states has widened the scope of its militarization and securitization in Africa. The role of military assistance, bureaucratic, and diplomatic ties, has enabled the US to strengthen its political, and military ties with African states in competition with China. In other words, while the US has lagged behind China in forging economic ties, and joint investment activities with African states, it has nonetheless developed a broad range of military ties with them such as joint military training exercises, weapons sales, signed overflight agreements, forged security agreements, and transferred millions in military assistance funds to states that are geostrategic in the fight against radical jihadism.

One of the latest developments in military security cooperation between the US and African states is what Steven Feldstein has described as "a continent-wide drone and surveillance network" . This network is comprised of locations in Cameroon, Burkina Faso, Chad, Djibouti, Kenya, the Seychelles, Somalia, and Uganda. These sites are engaged in intelligence gathering, surveillance, and reconnaissance operations. However, critics of this increasing securitization and militarization in the continent argue that the reason for this is misplaced and therefore is bound to be ineffective in the long

\footnotetext{
${ }^{5}$ Neuhaus L. US Military Stretched Thin in 50 African Nations // Observer. January 12, 2017. URL: https://observer.com/2017/12/us-military-has-presence-in50-of-54-african-countries/ (accessed: 11.01.2021). See also: [Luckham 1994].

${ }^{6}$ Feldstein S. Do Terrorist Trends in Africa Justify the U.S. Military's Expansion? // Carnegie Endowment for International Peace. February 9, 2018. URL: https://carnegieendowment.org/2018/02/09/do-terroristtrends-in-africa-justify-u.s.-military-s-expansion-pub75476 (accessed: 11.01.2021).
}

run. They argue that the military option should instead be a development option. The US military itself argues that the security threat in African states is really a consequence of misrule manifested in corruption, massive unemployment of youth, abuse of power by security forces, and a blatant lack of good governance. What will create stable societies in the continent will be investment in economic development and cooperation to ensure viable democracies.

Any focus on economic development is of course not a central focus of the US military. Another criticism leveled at expanding US militarization in Africa is that instead of decreasing terrorism, it could in fact aggravate it, unite extremist groups and provide more support for Jihadist leaders. The widening scope and intensity of militarization appears to have generated some backlash against some African and Western governments.

Third, the increasing presence of foreign militaries also helps to increase the authoritarian tendencies of incumbent African regimes who view foreign troops as protectors of their corrupt rule.

The US is aware of Africa's growing economic importance. The continent is home to some of the rapidly growing and enterprising middle class, countries with very encouraging growth in GDPs. The US is also aware that China is surpassing it in taking advantage of the best economic opportunities resulting in Chinese companies being overrepresented in the continent. By 2017 China's enterprises in Africa were in fact generating roughly 180 bln USD a year in revenue according to the report by McKinsey and Company Partner ${ }^{7}$. The continent has become not just a source of energy and other strategic resources but a huge market for China's affordable goods. The December 2017, National Security Strategy of the United States underscored Africa's growing importance when it stated that: "Africa remains a continent of promise and enduring challenges. Africa

${ }^{7}$ Sun Y.I., Jayaram K., Kassiri O. Dance of the lions and dragons: How are Africa and China engaging and how will the partnership evolve? // McKinsey and Company. June 2017. URL: https://www.africa-newsroom.com/files/ download/aa9f2979a3dc18e (accessed: 11.01.2021). 
maintains many of the world's fastest growing economies, which represent potential new markets for U.S. goods and services. Aspiring partners across the continent are eager to build market-based economies and enhance stability" ${ }^{8}$. China has been taking advantage of Africa's new and vibrant markets by "dumping" many of its goods which African consumers find more affordable than goods from the West.

Perhaps the most important reason for the US militarization and securitization of Africa is to create and maintain a world order favorable to US national interest and predicated on a neoliberal world order. This theme of a world order favorable to the US is inherent in or implied in virtually all the security strategies of the U.S. over the years [Mitzen 2006; Williams 2003; Baldwin 1997]. Accordingly, the US combats terrorism in Africa, helps enhance the military security of African states, and even tolerates authoritarian incumbent regimes because according to again the 2017 US National Security Strategy of December 2017: "Many African states are battlegrounds for violent extremism and jihadist terrorists. ISIS, al-Qaida and their affiliates operate on the continent and have increased the lethality of their attacks, expanded into new areas, and targeted U.S. citizens and interests"9.

The US may not be economically investing in Africa as extensively as China, but it makes sure it has a presence in all African states in the economic, military, and political realms. The presence of AFRICOM, the trade relationship of the African Growth and Opportunity Act (AGOA), the Emergency Plan for AIDS relief, the Power Africa Initiative, and the U.S. Africa Youth Program, among others, are all initiatives and cooperative efforts aimed at further incorporating Africa into the neoliberal world order with the aim of strengthening the peace, enhancing security, and forging multilateral ties to combat militancy and terrorism.

8 The 2017 National Security Strategy of the United States // Homeland Security Digital Library. URL: https://www.hsdl.org/?abstract\&did=806478 (accessed: 03.01.2021).

${ }^{9}$ Ibid. P. 4.
While combating terrorism to promote the neo-liberal world order, it is also concerned about China's role in Africa which is seen as undermining Africa's march towards a world order favorable to the United States. This concern is also articulated in the US National Security Strategy of 2017 in this way: "China is expanding its economic and military presence in Africa, growing from a small investor in the continent two decades ago into Africa's largest trading partner today. Some Chinese practices undermine Africa's long-term development by corrupting elites, dominating extractive industries, and locking countries into unsustainable and opaque debts and commitments"10.

\section{China's Role in the Militarization and Securitization of Africa}

Because of their largely pre-industrial condition and dependency situation, African states are often ready to embrace manufacturing and industrial projects initiated by more industrialized nations. It is therefore not a surprise that during the China - Africa Defense and Security Forum (CADSF) between June 26 and July 11 in 2016, the 49 African countries in attendance expressed their very strong support for China to strengthen African militaries with modern and technological security workshops/ courses $^{11}$. In addition, China has steadily engaged in the militarization of the continent through military aid such as the donation of $100 \mathrm{mln}$ USD extended to the African Union (AU) in 2017 to establish the African Union Standby Force $^{12}$; its ongoing military cooperation with the 55 members of the AU; and its active involvement in UN Peacekeeping Missions in the Democratic Republic of Congo, Darfur, Mali, and South Sudan, among others

10 Ibid.

11 Sun Y. US - China cooperation on African security // Brookings Institution. November 1, 2016. URL: https://www.brookings.edu/blog/africa-in-focus/2016/11/ 01/us-china-cooperation-on-african-security/ (accessed: 13.01.2021).

12 China to offer $\$ 100 \mathrm{~m}$ in military aid to African Union in next 5 years // Global Times. September 28, 2017. URL: https://www.globaltimes.cn/content/ 1068735.shtml (accessed: 14.01.2021). 
[Sautman, Hairlong 2013]. China's military engagement in many African countries and in the context of the AU is made easy through its extensive and deep involvement in the continent in the form of approximately hundreds of billions of dollars in economic investments; massive pledges of hundreds of millions of dollars in more investments during each Forum on China - Africa Cooperation (FOCAC); and the continuing influx of Chinese citizens into Africa as investors, miners, and tourists, among others. It is even estimated that the number of Chinese in Africa ranges between one and two million ${ }^{13}$.

The CADSF is likely to enhance China Africa military security interactions by widening the scope of military cooperation in the areas of their mutual security and increase the level of arms sales by China to African states. Already, China's arms sales to Africa have already increased significantly during the past five years largely because China targets African states with affordable weapons which largely fall into the SALW category ${ }^{14}$. Many of China's weapons are implicated in the atrocities that take place in many of the violent conflicts in Africa. The CADSF will enable China to further militarize the continent by making it easier to work out basing agreements with other African states following the example of its first ever foreign military base in Djibouti.

China now maintains diplomatic ties with all African nations, except Eswatini. Just as its arms sales which are nearing the $20 \%$ share $^{15}$ in relation to other powers, China will likely in the future expand its air and naval access in many parts of the continent. Within the context of CADSF China considers military cooperation with African states an aspect of and a need for collective security. Hu Changming, the General

${ }^{13}$ Hairong Y. We wanted to know if Chinese migrants in Africa self-segregate. What we found // The Conversation. June 4, 2020. URL: https://theconversation.com/ we-wanted-to-know-if-chinese-migrants-in-africa-selfsegregate-what-we-found-138829 (accessed: 14.01.2021).

14 Wezeman P.D., Fleurant A., Kuimova A., Tian N., Wezeman S.T. Trends in International Arms Transfers, 2017 // SIPRI. March 2018. URL: https://www.sipri.org/ sites/default/files/2018-03/fssipri_at2017_0.pdf (accessed: 14.01.2021).

${ }^{15}$ Ibid. P. 15.
Director of the Military International Office, Central Military Commission of China, expressed the mutual security cooperation between the two entities this way: "China will support the military transformation for African countries, provide equipment and advanced technology for African militaries, and support in building Africa's independent security"16.

With a statement like this, China is upstaging the US through rhetoric that implies that it cares more about Africa's development than the US does. The emphasis on collective security and transfer of advanced technology and pledging to build the continent's independent security is another way of reiterating its win-win strategy.

China seems to work hard at creating a positive image of itself while also promoting / guarding its investments in the continent. For example, its extensive involvement in peacekeeping and peacebuilding activities is now a well-known fact of its engagement with the continent. At the same time over the past decade its arms sales and military cooperation with African states has grown rapidly. In the 2018 FOCAC meeting China pledged funding for a China - Africa Peace and Security Fund, military assistance and 50 programs in law and order, peacekeeping, and anti-piracy, and counterterrorism. When looked at in total, China's military and security activities are wide ranging comprised of the CADSF, growing participation in UN Peacekeeping, funding to the tune of $100 \mathrm{mln}$ USD for an Africa Standby Force, and an increasing level of arms sales to specific African states ${ }^{17}$.

In fact, China has moved from an external power deploying small contingents focused on peacebuilding in the areas of medical services and engineering support to combat troops engaged in peace-enforcement in Mali, and

\footnotetext{
${ }^{16}$ Margai J.S. China - Africa Defense and Security Forum... // Concord Times. June 27, 2018. URL: http://slconcordtimes.com/china-africa-defense-and-securityforum/ (accessed: 14.01.2021).

17 Wezeman P.D., Fleurant A., Kuimova A., Tian N., Wezeman S.T. Trends in International Arms Transfers, 2017 // SIPRI. March 2018. URL: https://www.sipri.org/ sites/default/files/2018-03/fssipri_at2017_0.pdf (accessed: 15.01.2021).
} 
South Sudan, to an increased role in overall peacekeeping in Africa deploying more troops than any other permanent member of the UN Security Council. As of October 2018, they numbered $2506^{18}$. Besides, China has contributed to many other security related activities in Africa such as training of police and soldiers for peacekeeping, and supporting the AU in its objective of ensuring a more peaceful continent free of civil strife ${ }^{19}$. There has been a slow but steady trend towards militarization and securitization of Africa by China.

For well over two decades China emphasized its non-interference policy, its rhetoric of not mixing business with politics. Until the early 2010s China focused on playing the role of a responsible rising power in Africa through its focus on multinational peacekeeping and peacebuilding efforts in several countries on the continent. In postwar countries like Liberia it dispatched postwar reconstruction experts such as military engineers, medical staff and police training officials. China has been involved in peacekeeping missions in several countries on the continent.

While the US seems to be more involved than China in military and counterterrorism activities in Africa, China, according to Lina Benabdallah seems to be in the process of trying to extend its activities in the defense and military security area underlined by its win-win, or mutual benefit philosophy ${ }^{20}$. In addition to conducting joint military exercises, military training for all military officials, China's goal through the forum is to create far stronger military security ties between the People's

18 Kovrig M. China Expands Its Peace and Security Footprint in Africa // International Crisis Group. October 24, 2018. URL: https://www.crisisgroup.org/asia/northeast-asia/china/china-expands-its-peace-and-securityfootprint-africa (accessed: 15.01.2021).

${ }^{19}$ Ibid.

${ }^{20}$ Benabdallah L. China - Africa military ties have deepened. Here are 4 things to know // The Washington Post. July 6, 2018. URL: https://www.washingtonpost.com/ news/monkey-cage/wp/2018/07/06/china-africa-militaryties-have-deepened-here-are-4-things-to-know/?fbclid= IwAR3plOF7L4tSPtzY kdIxaqcpQxba4QKjHo6QWyDlB X_xuwxoeENRq36XXc (accessed: 16.01.2021).
Liberation Army, Navy, and Air Force and African military officers.

This decision to increase military and security ties is a realization of President Xi Jinping's promise in 2015 to help Africa establish an "African Standby Force" that would translate into the "African Capacity for Immediate Response to Crisis". During the Forum on China - Africa Cooperation (FOCAC, 2015), President Xi Jinping had promised 100 mln USD of free military aid to the African Union to be used towards this effort ${ }^{21}$.

China's decision to enhance the military and security defense of Africa also entails the holding of military workshops involving tens of thousands of top Chinese and African military officials in China. The current expansion of China - Africa military defense and security activities in Africa means that China's engagement in Africa has become even more multidimensional to comprise of economic, political, cultural, educational, military security and defense activities. In the military security and defense area China is known for its involvement in arms sales, anti-piracy training and deployment of troops to counter terrorism.

Because arms transfers by China to Africa largely fall into SALW category which are inexpensive and easy to use they have been implicated in ethno-political violence, government-rebel conflicts in countries such as Sudan, South Sudan, the Democratic Republic of Congo, Zimbabwe, and Central African Republic, among others. China's arms transfer militarization of the continent is now a reality because of its strategy of making its weapons: affordable or inexpensive; available for all because of its arms transfer or military relationship with both strategic and non-strategic African countries such as Egypt, South Africa, and Zimbabwe on the one hand, or Eritrea, Equatorial Guinea, Burundi, or Sierra Leone on the other; and aggressive and effective marketing

${ }^{21}$ Xue K. FOCAC 2015: Making sense of the numbers // China Africa Project. December 30, 2015. URL: https://chinaafricaproject.com/2015/12/30/focac-2015making-sense-of-the-numbers/ (accessed: 16.01.2021). 
of both its sophisticated and SALWs in frequent and regular arms exhibits within the continent.

In other words, China is ever present at arms trade shows in Africa and by 2012 was selling weapons to well over 15 countries in the continent, more than any other major arms exporter ${ }^{22}$.

\section{China's Geostrategy - Dilute U.S. Power Preponderance}

China's militarization and securitization of Africa is part of its strategy of promoting multipolarity and/or power dilution directed at the US. Accordingly, China securitizes US presence in order to weaken what China views as a US advantage related to its power preponderance in Africa and other regions of the world [Buzan 1991; Smith 2005; Waever 1995]. Multi-polarity is a key foreign policy strategy of China which it is pursuing in Africa through extensive and deep economic power projection in the continent; the forging of close economic ties with all African states that adopt the "One China" policy, and especially with significant geopolitical and economic states on the continent; and encouraging broad cooperation between Asian and African states, and reviving the Bandung Spirit, and in the case of Africa in particular making FOCAC an integral arm of China's foreign policy and diplomatic strategy aimed at outdoing the US presence on the continent.

Pursuing the three broad objectives outlined above have taken the form of activities that are economic (joint economic ventures with African states), political party cooperation, establishing Confucius Centers, aiding Africa's education goals, and more recently deeper cooperation with Africa in matters of military defense and security, among many other development-related activities. China views Africa as a region of high priority to its overall international relations and that is why it engages in high level diplomacy by embarking on more frequent and regular visits by its heads of states compared to the US.

22 Lynch C. China's Arms Exports Flooding Sub-Saharan Africa // The Washington Post. August 25, 2012. URL: https://www.washingtonpost.com/world/ national-security/chinas-arms-exports-flooding-subsaharan-africa/2012/08/25/16267b68-e7f1-11e1-936ab801flabab19 story.html (accessed: 16.01.2021).
In fact, China has now made it a diplomatic tradition of its foreign minister to pay the first foreign visit of each year to an African state ${ }^{23}$. Besides, Chinese heads of state since the 1960s have been accustomed to visit Africa on a regular basis. The continent is given diplomatic, economic, political, and even military attention above other regions.

Furthermore, the US power de-concentration that China is pursuing in Africa is in line with the overall goal of China's foreign policy which is to create a more multipolar world. For instance, in 2001, as Vice President of China, Hu Jintao declared that "Multipolarity composes an important base for achieving a durable peace on the planet. Such Multipolarity is conducive to building a new just and reasonable economicpolitical order, setting up a relatively stable international political framework, and promoting exchanges and cooperation" 24 .

First, China is convinced that a very effective way to undermine US power preponderance is to employ its enormous and growing economic strength and forge cooperative strategic partnerships with the nation-states of Africa.

Second, China makes sure that it especially develops significant partnerships with the more strategic states in Africa such as South Africa which is a member of the BRICS nations considered emerging potential great powers. Apart from South Africa, China has a significant presence in anchor states such as Nigeria, Kenya, Ethiopia, and Egypt. China's continuous wooing of both significant and non-strategic African states could be interpreted as a deliberate strategy by China to ensure US power / influence dilution and offer an alternative great-power ally to weaker nations instead of their total dependence on the United States [Alden 2007; Shinn, Eisenman 2012]. African states such as Sudan and Zimbabwe which have been the target

${ }^{23}$ Biegon E. Why Foreign Minister Wang Yi's Africa tour is crucial // China Plus. January 13, 2018. URL: http://chinaplus.cri.cn/opinion/opedblog/23/20180113/775 14.html (accessed: 17.01.2021).

24 Multipolarity Plays Key Role in World Peace: Chinese Vice President // People's Daily. November 8, 2001. URL: http://en.people.cn/english/200111/05/ eng20011105_83945.html (accessed: 17.01.2021). 
of Western sanctions have often turned to China as an alternative and an escape from dependence on the US or the West in general. For instance, during the Communist Party Congress in 2017, President Xi said that China's socialist economy serves as an alternative to other systems ${ }^{25}$.

Third, China's focus on creating a more symmetric / multipolar international system is seen in its establishment of the Asian Infrastructure Investment Bank (AIIB) as an alternative or competitor to the US dominated World Bank. The AIIB reflects the financial power of China, and is an instrument in promoting multipolarity, reawakening the Bandung Spirit aimed at uniting Asian, African, and other Third World regions. The BRICS Development Bank is also a part of this strategy by China.

China, it could be argued is using Africa to pursue its de-concentration of US power and influence and create a more symmetrical power relationship among great powers and African states. First, China's efforts at weakening US power has taken the form of establishing strategic partnership with states defined as forging close cooperation with them in economic, political, cultural, educational, and security areas, among other things.

Through this partnership it is hoping to achieve power and influence parity with the US in Africa. This new strategic partnership is advantageous to China because it can count on friends in Africa should it someday have to confront global sanctions directed against it by the West or the United Nations. In the worst case scenario, it could also have support from African friends should it someday be caught up in a militarized dispute with the US. Second, China openly states that it is more focused on business than on military alliances, and in particular says that it does not mix business with politics.

${ }^{25}$ Denyer S. Move over, America. China now presents itself as the model 'blazing a new trail' for the world // The Washington Post. October 19, 2017. URL: https://www.washingtonpost.com/news/worldviews/wp/20 17/10/19/move-over-america-china-now-presents-itself-asthe-model-blazing-a-new-trail-for-the-world/ (accessed: 18.01.2021).

\section{The Role of Discourse in U.S. - China Rivalry}

I argue that hegemonic rivalry is closely associated with discursive hostility or allusions. A discourse is hostile or adversarial when it directs or imputes negativity or wrong motives to another nation-state / rival perceived as threatening, or undermining the dominance, or the status quo at the expense of the state viewed as the current hegemon. In the case of US China hegemonic rivalry in Africa it is worthwhile to examine the sources / types of discursive hostility directed at China for its engagement with Africa. First of all the reasons for the intensification of discourse hostility directed at China are easily manifested in China's phenomenal increase in Digital financial inclusion (DFI) in Africa; its status in 2009 as Africa's biggest trading partner surpassing trade with the US, the EU, and other large trading blocs. This hostility is expressed by public officials whose functions are in the area of US Africa relations [Cohen 2019].

The response of these public officials is not so much a response against the economic engagement between China and Africa but an expression of US insecurity regarding China's rise and growing influence on the continent. Narratives directed at China focus on its cozy relationship with repressive regimes on the continent, its lack of concern for systemic corruption and corrupt practices by political elites, and a process of undermining democracy.

The framing of China's engagement on the continent is labeled as a recolonization of the continent. In 2018 Representative Chris Smith, the Chairman of the US Subcommittee on Africa Global Human Rights and International Operations stated that China is trying to "undo much of the progress that has been made on democracy and governance in the last 15 years in African nations" 26 . In a similar vein, Assistant Secretary of State, Johnnie Carson in February

26 China in Africa: The New Colonialism? Hearing Before the Subcommittee on Africa, Global Health, Global Human Rights, and International Organizations of the Committee on Foreign Affairs House of Representatives: One Hundred Fifteenth Congress. March 7, 2018. URL: https://www.govinfo.gov/content/pkg/CHRG-115hhrg28876/ pdf/CHRG-115hhrg28876.pdf (accessed: 20.01.2021). 
2010 stated that "China is a very aggressive and pernicious economic competitor with no morals" ${ }^{27}$. This was in reference to its economic role in Africa. In 2018, former Secretary of State, Rex Tillerson, warned against African nations accepting China's loans and be wary of concluding agreements which would make them lose their sovereignty ${ }^{28}$. Former Secretary Tillerson, further stated that China encourages dependency, and utilizes corrupt deals that endanger Africa's natural resources ${ }^{29}$.

The leit motif of top US diplomats regarding China in Africa is warnings against China's transactions with African nations. In February 2020, former Secretary of State Mike Pompeo during his three nations (Senegal, Angola, and Ethiopia) tour of Africa warned African nations to be wary of "empty promises from authoritarian regimes" 30 . This was a reference to China's many promises to African nations in bilateral and multilateral relationships. $\mathrm{He}$ emphasized in his speech on February 19, 2020 in Addis Ababa, Ethiopia that "true liberation" resided in economic ties with the United States ${ }^{31}$.

When examined closely, the barrage of negative discourse directed at the Sino-African relationship could be summarized as a situation whereby China poses a developmental threat to Africa. In the area of the progress towards liberal democracy, for instance, China is viewed as sabotaging the neo-liberal democratic capitalist order on the continent ${ }^{32}$. In its discourse, the US

27 US: China lacks 'morals' in Africa // Aljazeera. February 9, 2010. URL: https://www.aljazeera.com/news/ 2010/12/9/us-china-lacks-morals-in-africa (accessed: 20.01.2021).

28 Maasho A. Africa should avoid forfeiting sovereignty to China over loans: Tillerson // Reuters. March 8, 2018. URL: https://www.reuters.com/article/ us-usa-africa-idUSKCN1GK114 (accessed: 20.01.2021).

${ }^{29}$ Ibid.

30 Bearek M. Promising 'true liberation,' Pompeo contrasts U.S. role in Africa with China's // The Washington Post. February 19, 2020. URL: https://www.washingtonpost.com/world/africa/promisingtrue-liberation-pompeo-contrasts-us-role-in-africa-withchinas/2020/02/19/4aa50280-52ef-11ea-80ce-

37a8d4266c09 story.html (accessed: 20.01.2021).

${ }^{31}$ Ibid.

32 Campbell J. U.S. Africa Policy Needs a Reset // Foreign Affairs. October 12, 2020. URL: https://www.foreignaffairs.com/articles/africa/2020-1012/us-africa-policy-needs-reset (accessed: 20.01.2021). underscores a great deal of intangible rhetoric focused on human rights, democracy promotion or the rule of law in general. While all these are laudable, the problem is they are devoid of, or pale in comparison with tangibles like roads, ports, dams, railways that have visible and immediate effects on personal, community, and even national livelihoods or existential security.

US discourse directed at China is no doubt powerful and makes sense from an economic point of view. One such discourse is the fact that China's manufacturing activities in Africa are growing and that this has the effect of being harmful to African local infant industries in Africa. China's relatively advanced manufacturing status will have the effect of marginalizing locally produced goods in African countries and thereby stifle the growth of these local indigenous factories / industries.

China on the other hand, directs its discourse at Africa when it is in fact targeting the United States. For instance, China makes constant reference to shared interests with Africa, and stating that it is even bound by common political-historical ties with the continent. For instance, President Xi Jinping when addressing African leaders stated that "China and Africa share mutual needs and complementarities and face a rare opportunity in pursuing development through cooperation" $" 33$. Moreover, China seizes on the intangible aspects of human rights, democracy promotion by stating that its own human rights priorities, economic human rights are more relevant for Africa than political right and civil liberties. This is because, it argues, tangibles like a railway system, phones, roads, or hospitals are more beneficial to Africans than vague concepts like democracy or human rights.

A great deal of the discourse / narratives are predicated on power political and economic rivalries and geopolitics and expressed in synonyms, metaphors, analogies and found in

33 Address by H. E. Xi Jinping, President of the People's Republic of China, at the Opening Ceremony of the Johannesburg Summit of The Forum on China-Africa Cooperation, 4 December 2015 // Department of International Relations and Cooperation. Republic of South Africa. December 4, 2015. URL: http://www.dirco.gov.za/ docs/speeches/2015/xi1204.htm (accessed: 20.01.2021). 
official speeches, policy documents, books or articles, among others. These competing narratives directed at each other are an example of hegemonic geo-spatial regional rivalry between the U.S. and China in Africa.

The radical clash in worldviews between the U.S. and China makes a great deal of the rhetoric as a discursive competition between a capitalistdemocratic system and a rising China promoting a new and seemingly impressive model of capitalist dictatorship. The fear is that if the China Model (capitalist authoritarianism) takes deeper roots in Africa it may end up being adopted wholesale thereby wiping out all traces of democracy even in more progressive African states like Kenya, Senegal, South Africa and Nigeria, among others. In particular, the clashing narratives related to US - China rivalry in Africa revolves around: China's impressive power-economic rise and its attendant extensive economic power projection into Africa; and the geopolitical insecurity on the part of the US that China's capitalist dictatorship governance model may end up displacing the Western Consensus. This is especially so since China's relationship with African countries is free of political and economic conditional ties (austerity measures) that are resisted and resented by many incumbent regimes on the continent.

\section{China's Vaccine Diplomatic Offense}

China's discourse on Africa has consistently been underlined by what could be considered genuine concern for the welfare of Africa nations as manifested in the refrain of "win-win" relationship. With COVID-19 China has consistently embarked on what has been referred to as vaccine diplomacy. China or entities connected to the Chinese state have engaged in the most robust vaccine diplomacy either through promises to African nations, tangible donations, or actual COVID-related supplies.

At both the level of the Chinese state, SOE's, and private Chinese firms, and even individual, donations have already poured into Africa in the form of masks, testing kits, and upgrading hospitals, surgical masks, infrared thermometers, bottles of sanitizers that would be needed to treat COVID-19 cases. One of the advantages of China's diplomatic offensive against the U.S. is that China even involves African countries and updates them on its vaccine development. In 2020, 50 African diplomats in China visited a SinoPharm factory $^{34}$, China also held a China - Africa Summit on Solidarity against COVID-19. COVID-19 has enabled tighter linkages between China's SOEs and private Chinese firms and African economic entities. In South Africa China's COSCO Shipping donated about 10,000 medical masks and 200 bottles of hand washing gel to Transnet, South Africa's national freight and logistics group ${ }^{35}$.

In Ghana, another Chinese SOE Jianxi International Economic and technical Cooperation Co. donated 10,000 masks to its Ghanian counterpart, Ministry of Roads and Highways ${ }^{36}$. In Nigeria the Chinese Construction and Civil Engineering Company (CCCEC) provided cash, face masks, sanitizers, and rice to the Lagos state government in Nigeria ${ }^{37}$.

All these examples are focused on cementing relationships between the company and the African company, and overall create a diplomatic advantage for China in its competition with the United States.

The activities of the Chinese state, SOEs, private firms, and individual donors project an image of a China that is very willing and ready to combat the virus in Africa. The Chinese state is even pushing the narrative that its vaccine is more suitable to the climatic conditions in Africa. The BBIBP-CorV developed by the Chinese National Pharmaceutical Group (SinoPham). China argues that as an inactivated vaccine it has an advantage because it does not need to be stored between -20 and $-70 \mathrm{C}^{\circ}$ like the mRNA vaccines of Pfizer and Moderna ${ }^{38}$.

34 Bone M.R., Cinotto F. China's Multifaceted COVID-19 Diplomacy across Africa // The Diplomat. November 2, 2020. URL: https://thediplomat.com/2020/ 11/chinas-multifaceted-covid-19-diplomacy-across-africa/ (accessed: 21.01.2021).

35 Ibid.

${ }^{36}$ Ibid.

${ }^{37}$ Ibid.

38 Campbell J. Vaccine Diplomacy: China and SinoPharm in Africa // Council on Foreign Relations. January 6, 2021. URL: https://www.cfr.org/blog/ vaccine-diplomacy-china-and-sinopharm-africa (accessed: 25.01.2021). 
In sum, China's response to COVID-19 in Africa is both a public relations strategy and a deliberate way to frame itself as the foremost solution to the pandemic in Africa, a continent that is being marginalized by the ongoing vaccine nationalism - a process whereby the US and European nations have prioritized the interest of their citizens by contracting with Pfizer and Moderna for supplies. China's vaccine diplomacy is aimed at helping to alleviate the concerns of African states. This means that China's response to COVID-19 in Africa constitutes a diplomatic advantage over the US; creates an opportunity for it to enhance its image among African states; and cements its economic and political ties through donations at all levels from the Chinese state to private citizens.

\section{Conclusion}

In conclusion, both the United States and China in their rivalry in Africa utilize specific strategies to counteract the influences of each other. To be specific, this article examined in some depth the strategies of militarization and securitization, as well as competing discourse or narratives utilized by both powers. These strategies are in turn linked to the promotion and safeguard of their political, economic, cultural, and diplomatic interests on the continent. China's phenomenal rise and interest in the continent, which is reflected in activities ranging from mineral extraction, medical work, infrastructural projects, agricultural cooperation to increasing military ties have ignited hegemonic insecurity on the part of the United States and has fueled this rivalry. China's engagement with the continent has especially been multi-pronged and has ranged from the political-economic to the socio-cultural. The goal according to China's political elite is to dilute US power in the continent and enhance multipolarity in the international system in general. China may be using Africa as an instrument of for containing US power preponderance, to sell the Chinese model, and even promote its Belt and Road Initiative.

Received / Поступила в редакцию: 31.01.2021 Accepted / Принята к публикации: 02.04.2021

\section{References / Библиографический список}

Albrecht, U. (1977). Technology and militarization of Third World countries in theoretical perspectives. Bulletin of Peace Proposals, 8(2), 124-126.

Alden, C. (2007). China in Africa (African arguments). London: Zed Books.

Baldwin, D. (1997). The concept of security. Review of International Studies, 23(1), 5-26. https://doi.org/10.1017/S0260210597000053

Balzacq, T. (2005). Three faces of securitization: Political agency, audience and context. European Journal of International Relations, 11(2), 171-201. https://doi.org/10.1177/1354066105052960

Buzan, B. (1991). People, states and fear: An agenda for international security studies in the post-Cold War era. Boulder, CO: Lynne Rienner Publishers.

Cohen, H. (2019). US policy toward Africa: Eight decades of Realpolitik. Boulder, CO: Lynne Rienner Publishers.

Conteh-Morgan, E., \& Weeks, P. (2016). Is China playing a contradictory role in Africa? Security implications of its arms sales and peacekeeping. Global Security and Intelligence Studies, 2(1), 81-102. https://doi.org/ $10.18278 / \mathrm{gsis} .2 .1 .6$

Gelot, L., \& Sandor, A. (2019). African security and global militarism. Conflict, Security and Development, 19(6), 521-542. https://doi.org/10.1080/14678802.2019.1688959

Hong, Z. (2008). China - U.S. oil rivalry in Africa. The Copenhagen Journal of Asian Studies, 26(2), 97-119. https://doi.org/10.22439/cjas.v26i2.2240

Keenan, J. (2008). US militarization in Africa: What anthropologists should know about AFRICOM. Anthropology Today, 24(5), 16-20. https://doi.org/10.1111/j.1467-8322.2008.00613.x

Luckham, R. (1994). The military, militarization and democratization in Africa: A survey of literature and issues. African Studies Review, 37(2), 13-75. https://doi.org/10.2307/524766

Mazrui, A.A. (1986). Africa: A triple heritage. London: BBC Books.

Mitzen, J. (2006). Ontological security in world politics: State identity and the security dilemma. European Journal of International Relations, 12(3), 341-370. https://doi.org/10.1177/1354066106067346 
Nsia-Pepra, K. (2014). Militarization of U.S. foreign policy in Africa: Strategic gain or backlash? Military Review, 94(1), 50-58.

Sautman, B., \& Hairong, Y. (2013). Friends and interests: China's distinctive links with Africa. African Studies Review, 50(3), 75-114. https://doi.org/10.1353/arw.2008.0014

Shinn, D., \& Eisenman, J. (2012). China and Africa: A century of engagement. Philadelphia: University of Pennsylvania Press.

Smith, S. (2005). The contested concepts of security. In K. Booth (Eds.), Critical security studies and world politics (pp. 27-62). Boulder, CO: Lynne Rienner Publishers.

Waever, O. (1995). Securitization and desecuritization. In R.D. Lipschultz (Eds.), On security (pp. 46-86). New York: Colombia University Press.

Wendt, A., \& Barnett, M. (1993). Dependent state formation and Third World militarization. Review of International Studies, 19(4), 321-347.

Williams, M. (2003). Words, images, enemies: Securitization and international politics. International Studies Quarterly, 47(4), 511-531. Retrieved from https://studylib.net/doc/8230405/words--images--enemies-securitization-and-international-...

\begin{abstract}
About the author: Conteh-Morgan Earl - PhD in International Relations, Professor of International Studies, School of Interdisciplinary Global Studies, University of South Florida; ORCID: 0000-0002-5304-1039; e-mail: conteh@usf.edu
\end{abstract}

Сведения об авторе: Конте-Морган Эрл - доктор наук в области международных отношений, профессор международных исследований Школы междисциплинарных глобальных исследований Университета Южной Флориды; ORCID: 0000-0002-5304-1039; e-mail: conteh@usf.edu 